\title{
EML4/ALK Fusion Gene Variant 4
}

National Cancer Institute

\section{Source}

National Cancer Institute. EML4IALK Fusion Gene Variant 4. NCI Thesaurus. Code C99730.

A fusion gene ( $3.4 \mathrm{~kb})$ that results from a chromosomal inversion inv(2)(p21p23) which fuses exon 14 of the EML4 gene and an 11 nucleotide linker sequence with exons 20-29 of the ALK gene. This fusion is associated with non-small cell lung cancer. 